\title{
A sceptic and an empiric in medicine: George Young (1692-1757) and the beginnings of the Scottish medical Enlightenment
}

\author{
IMC Macintyre \\ Retired Surgeon and History Editor of the Journal of the Royal College of Physicians of Edinburgh, Edinburgh, UK
}

\begin{abstract}
The Edinburgh surgeon-apothecary and physician George Young was an empiric who emphasised observation, practical experience and a sceptical approach to evidence in medicine. He was an early member of the Rankenian Club, a group of young intellectuals whose ideas were to be at the heart of Scottish Enlightenment thinking. Young certainly influenced his pupil Robert Whytt, who went on to make important contributions to the understanding of nerve and muscle function. James Hill,Young's apprentice, to whom he emphasised the importance of experience and observation, would later advance thinking and practice in the management of head injury. Young was an important, but to date relatively neglected, figure in the early years of the Edinburgh Medical School and the Scottish Enlightenment. This paper describes what is known of his life and work, aims to assess his legacy and suggests that he deserves greater recognition and appreciation.
\end{abstract}

\author{
Correspondence to IMC Macintyre \\ 20 Lygon Road, \\ Edinburgh EHI6 5QB, UK \\ e-mail \\ iainmacintyre@blueyonder.co.uk
}

KEYWORDS George Young, Rankenian Club, Edinburgh surgeon and physician, philosopher, Treatise on Opium

DECLARATION OF INTERESTS IMC Macintyre is the History Editor of The Journal of the Royal College of Physicians of Edinburgh. This article was submitted to, and handled exclusively by, the JRCPE's Editor and has been peer-reviewed in line with standard JRCPE procedures.

George Young was born in Edinburgh in 1692, into a family who were brewers on the Water of Leith, with his father and brothers Alexander, Robert and Thomas all involved in the family business.' Nothing is known of his schooling, but on I4 March I7II he was apprenticed to the Edinburgh surgeon-apothecary Alexander Simpson. ${ }^{2,3}$ The majority of the Edinburgh surgical apprentices did not proceed to sit the examination of the Incorporation of Surgeons and Barbers, ${ }^{4}$ but becoming a master or freeman of the Incorporation conferred higher status and the possibility of a more lucrative practice. In July 1719 Young sat the Incorporation examination in four parts, each a month apart, as was customary at that time..$^{5}$ The examination topics are recorded in the minutes of the Royal College of Surgeons of Edinburgh (RCSEd) and a candidate's choice of subject for his discourse can often give a guide to his current or future interests. In Young's case the topics on which he was examined included the operation of 'empioma' (presumably the drainage of empyema), the operation of bronchotoma (tracheotomy), the spleen, the fetal circulation and scarf skin (epidermis). The topic on which he chose to give his discourse was 'muscular motion' which, as discussed later, was to remain a subject that continued to fascinate him. ${ }^{5}$ Young was admitted to the Incorporation (roll number 169), some three months before his near contemporary Alexander Monro primus.
Many Edinburgh surgeon-apothecaries at this time had apothecary shops ${ }^{4}$ and a Burgess ticket was required to practise. Young obtained this on 27 May 1719, becoming a Burgess and Guild brother through his marriage to Janet Ross, daughter of Robert Ross, writer [to the Signet] (i.e. solicitor) to the Incorporation of Skinners and Furriers. ${ }^{2}$ George Young seemed set for a career as an Edinburgh surgeon-apothecary, but he was to prove no ordinary surgeon. Around this time he joined the Rankenian Club, the only surgeon known to have done so.

\section{THE RANKENIAN CLUB}

Learned clubs and societies were a feature of the Scottish Enlightenment and the Rankenian Club was one of the most important. ${ }^{6,7}$ Founded around 1716-9 by a group of Edinburgh students with the aim of stimulating literary and philosophical discussion, its influence was described by the Scots Magazine of May 177I. 'It is well known that the Rankenians were highly instrumental in disseminating throughout Scotland freedom of thought, boldness of disquisition, liberality of sentiment, accuracy of reasoning, correctness of taste and accuracy of composition.' No less a figure than the philosopher Dugald Stewart confirmed this assessment in his book on the life of William Robertson. ${ }^{8}$ The club was named 
for the venue in which they met, Ranken's Tavern on the west side of Hunter's Square, just off the High Street.' One of the earliest topics they discussed was the complex 'immaterialism' philosophy of Bishop Berkeley with whom they corresponded; their intellectual stature was confirmed by a letter from Berkeley complimenting them on their understanding of his theories. ${ }^{10,11}$ It is worth noting Young's early membership of this club as it included several young men who were to go on to make significant academic contributions and in many instances were to become 'literati', teachers and leaders of the Scottish Enlightenment. Young's contemporaries in the club included Charles Mackie (1688-1770), later the first professor of history at the University of Edinburgh; John Stevenson (1695-1775), later professor of logic and rhetoric; George Turnbull (1698-1748), theologian and professor of moral philosophy at Marischal College, Aberdeen; Robert Wallace (1697-I77I), theologian and population scientist; William Wishart (I69I-I753), leading church minister and principal of Edinburgh University and Colin MacLaurin (1698-1746), philosopher, protégé of Isaac Newton and the greatest Scottish mathematician of his day. ${ }^{12}$ Later physician members included Alexander Dick (1703-1785) who became president of the Royal College of Physicians of Edinburgh (RCPE) and John Pringle (I707-I782), later professor of moral philosophy at Edinburgh University and president of the Royal Society of London. ${ }^{6,13}$

It is not clear how Young became a member of such an illustrious group. Other members appear to have been university students, and indeed more than one account suggests that the club was 'strictly for graduates only'. 9, 14 In the tradition of the surgeon of his day, however,Young did not matriculate, let alone graduate, at this stage in his career. Indeed there was no formal medical course at Edinburgh University at this time, although the University granted 21 MD degrees between 1705-1726, half of these to Scots. ${ }^{15}$ Before 1719 only two Edinburgh surgeon-apothecaries had MD degrees, Christopher Irvine (1620-1693) and Archibald Pitcairne (1652-I713), both of whom practised as physicians. ${ }^{16}$ Young's membership of this elite club is the first indication of his considerable intellect. His place as a philosopher has been acknowledged by an entry in the Dictionary of Eighteenth Century British Philosophers, but the account is, perforce, based entirely on his lecture notes and treatise on opium which are both considered below. ${ }^{17}$

\section{YOUNG'S CAREER}

From 1720 Young began to practise as a surgeonapothecary in Edinburgh. The teaching of medicine had gained momentum in Edinburgh in the early years of the eighteenth century. The Incorporation of Surgeons had in 1705 appointed Robert Elliot as teacher of anatomy,

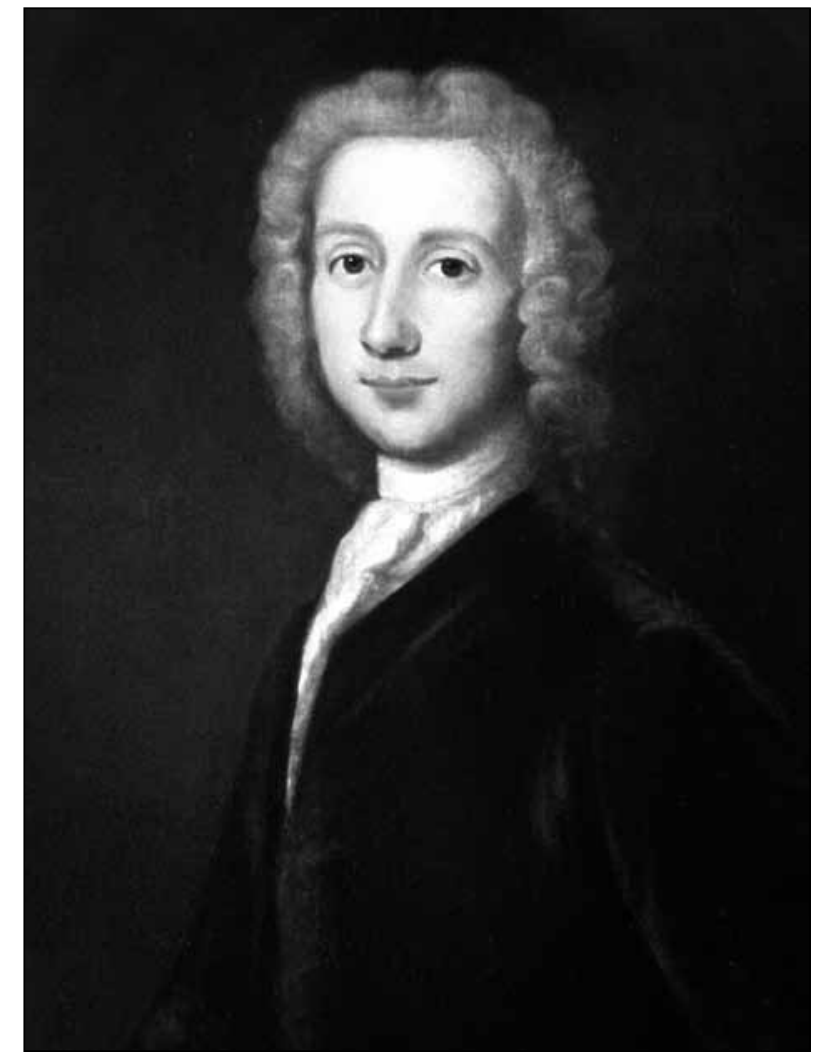

FIGURE I Robert Whytt (17|4-|766). The Edinburgh physician who recorded Young's lectures and subsequently made major contributions to the understanding of nerve and muscle function. Courtesy RCPE.

later joined by Adam Drummond, in 1717 by John McGill and three years after that by Alexander Monro primus. Charles Alston gave extramural classes in botany and from 1713 James Crawford taught chemistry and medicine. ${ }^{18}$ Persuaded by political lobbying and encouraged by the success of this extramural teaching, the Town Council established the University medical school in 1726 with the transfer of Monro's Anatomy chair from Surgeons' Hall into the University and the establishment of four chairs of medicine and one of midwifery. ${ }^{19}$ Such was the demand for medical teaching that the extramural tradition flourished in parallel with the University medical school. Young delivered medical lectures in Edinburgh and those he gave in 1730-I were recorded by Robert Whytt (Figure I), who himself was to make a significant contribution to the understanding of the nervous system, as discussed below. ${ }^{20}$

Young continued to practise as a surgeon, as demonstrated in RCSEd minutes by his attendance at Incorporation meetings and also by his continued training of surgical apprentices. ${ }^{3}$ Between 1720 and 1754 he trained a total of twelve apprentices. ${ }^{3}$ Yet he appears to have been attracted to a career as a physician. To practise as such in Edinburgh required that he become a licentiate of the RCPE, which meant passing the licentiate examination. 


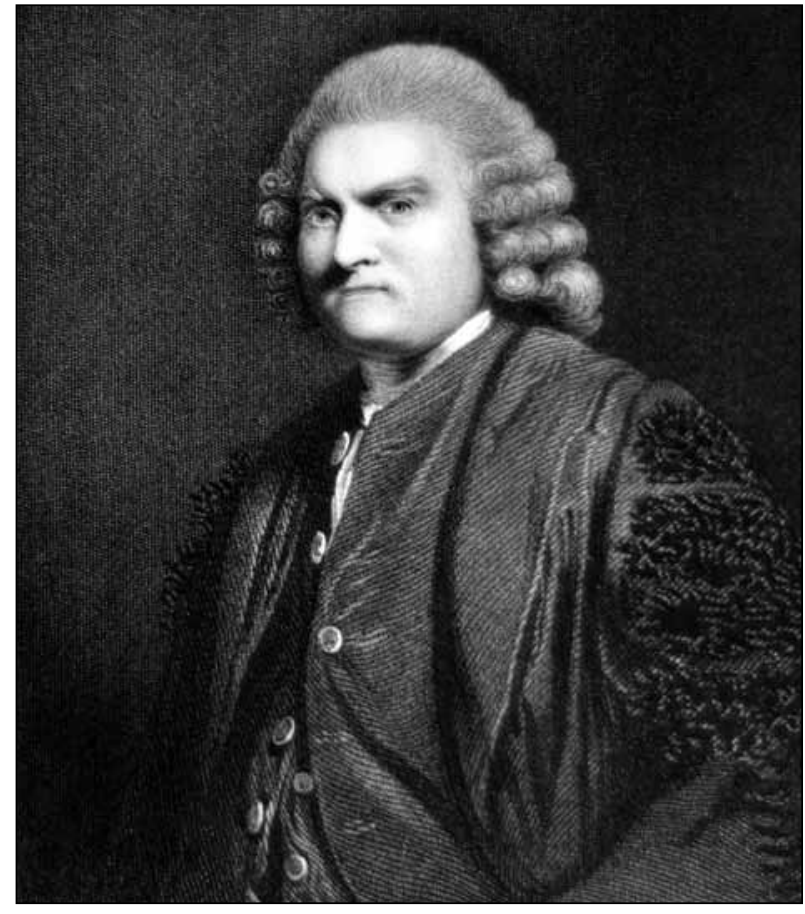

FIGURE 2 Sir John Pringle (1707-1782) was a fellow member of the Rankenian Club. He later attended Young's lectures and was a member of the RCPE committee which made Young a College licentiate. Pringle went on to a distinguished career as a military physician.Courtesy RCPE.

Those who held Scottish medical degrees were exempted from this (although those with degrees from continental European universities were not). The University of St Andrews was renowned for awarding such degrees without examination, and on 21 June 1736 Young was awarded the degree of MD (St Andrews) in absentia 'on account of his communicating to the public a secret for the cure of the dysentery and on account of his good character, for his known skill in all parts of medicine and his successful practice therein'. ${ }^{21}$ The following year he successfully applied to became a licentiate of the RCPE, where those who sat to consider his application included two of the inaugural professors of medicine at Edinburgh, Drs Plummer and St Clair, and Dr (later Sir) John Pringle, (Figure 2) the latter a fellow Rankenian who had earlier attended Young's lectures. Young's career seems to have flourished as he lived in a prestigious area of the town, in a large flat in Paterson's Court, Lawnmarket (now occupied by Deacon Brodie's tavern). ${ }^{22,23}$

In 175 I he and his son Thomas were able to rent extensive land in Harprig and Torphichen in what is now West Lothian. Thomas's will in 1755 suggests considerable family wealth. ${ }^{24}$ Thomas Young was appointed Professor of Midwifery at Edinburgh in 1756, the year before his father's death. He went on to a successful career in that speciality, credited with setting up, at his own expense, the first lying-in ward in Scotland in Edinburgh Royal Infirmary. ${ }^{25}$

\section{YOUNG'S PERSONALITY}

Although described by one of his pupils as a 'very sensible, honest, good-natured man', other sources show a determined, perhaps even domineering side to George Young's character. ${ }^{20}$ The most revealing insights come from papers that show his relationship to his son George. Young intended that his two sons, George, born around 1718 and Thomas, born around 1726 would follow him into medicine. In October 1738 George junior, having served as an apprentice and attended his father's apothecary's shop, was sent to Paris to walk the wards of the great teaching hospitals. ${ }^{26}$ In an accompanying letter his father wrote that his son "has been used to no degree of luxury or elegance..., that his usual fare was 'pottage and milk' and that he was to be 'kept free of company until his studies are over.'27 The recipient of the letter was Aeneas MacDonald, the Paris-based Scots banker (later one of the Seven Men of Moidart, subsequently found guilty in London of high treason for his role in handling the finances of Prince Charles Edward Stuart, but pardoned and returned to Paris where he resumed banking.) He was authorised to make payments to George junior for living expenses in Paris, and after 12 months these seemed reasonable at $£ 100^{26}$ (around $£ 8,500$ in buying power in 2005). ${ }^{28}$

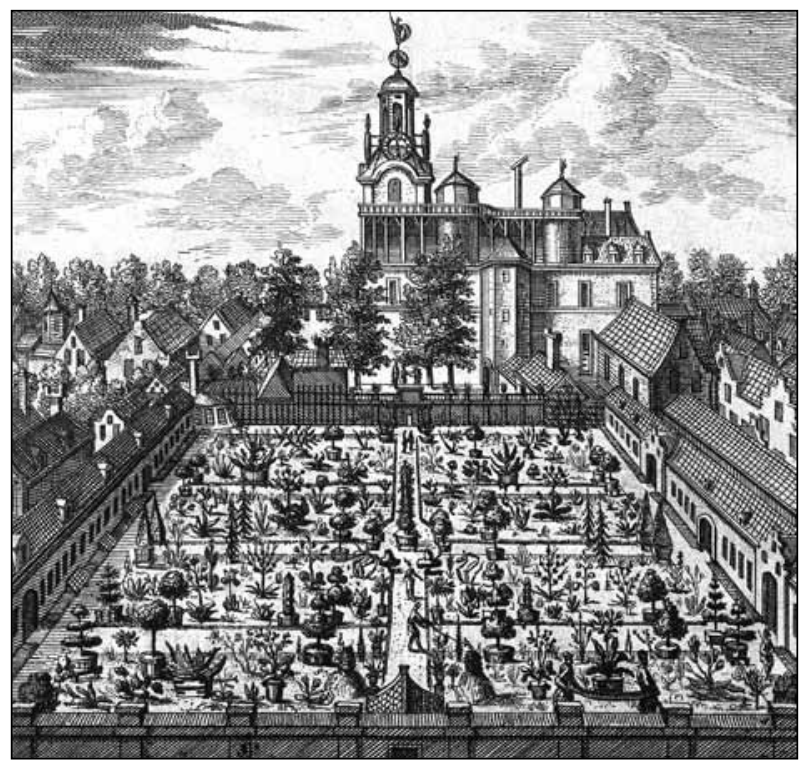

FIGURE 3 Leiden University and physic garden where George Young junior was sent to study medicine. The consequences of his hedonistic lifestyle and extravagant spending there may well have been factors which ultimately contributed to his father's loss of influence among his contemporaries. Courtesy Wellcome Library, London.

In October 1739 after a year in Paris, George enrolled at the University of Leiden (Figure 3) to study medicine. ${ }^{29}$ Aeneas MacDonald arranged for Messers Grant and Crawford, his agents in Rotterdam, to continue to make payments to him. By now however 
young George had acquired tastes for those luxuries denied him in Edinburgh. In his first year the largest sums paid to him were for wines and spirits (claret, rhenish and arrack), tea, chocolate and 'Gentlemens' Magazine'. ${ }^{26}$ By pretending to pay for books and tuition fees he was able to limit his spending to $£ 100$ in the first year. But over a ten-day period in May $174 \mathrm{I}$ he requested, and was paid, a total of $£ 252$, to cover, he claimed, books and his travel to London, where, at his father's request, he was to watch 'a curious operation'. His father had made no such request and refused to reimburse the agents, who began court proceedings against the Youngs to recover their payments. ${ }^{26}$

George junior's reason for travelling to England was very different, and this, and the events which followed, have been set out and analysed in some detail by Houston and van der Heijden. ${ }^{23}$

Over his 20 months in Leiden George had courted a local girl, Margaretha Cassa and, to her parent's consternation, announced his intention to marry her. $\mathrm{He}$ spent little time studying, but rather, as evidence to a later court case suggested, spent time '...coming every hour sauntering before their [the Cassa's] house...'

Claiming that he had parental permission to wed, George junior travelled with Margaretha to Colchester in Essex, where, having paid a $£ 200$ bond, they were married on May 19, I74I. Six weeks later Margaretha wrote from honeymoon in Paris telling her parents that she was pregnant, and, as her husband had to return to Scotland on unspecified business, she was returning alone to Leiden. The reason for his sudden return to Scotland proved to be a letter from his father telling him that he was in disgrace, but promising rehabilitation if he returned home. Margaretha's son was born in 1742. Her letters to her husband went unanswered, but in 1748 she received a letter (apparently from a well-wisher) inviting her to come to Edinburgh to join her husband. The letter was in fact from George Young senior, written with the aim of getting her to testify to a tribunal that she had never married his son. She proved however to be a feisty individual who began her own legal action, an adherence case, before the Edinburgh Commissary Court, aiming to prove that she was George Young's lawful wife and that her son was legitimate. Her action alleged that 'Dr Young the father had either induced, persuaded, compelled or threatened his son' to desert her. This allegation seems to have been justified, since George Young senior had written to Margaretha's parents in $1742^{\prime}$ '...my eldest son is disinherited and banished forever. You cannot comfort him.' He had then compounded the situation by imposing a declaratory of silence (gagging order) on his son. When it began to look as though Margaretha might win her case, George
Young senior offered her $£ 70$ sterling if she would divorce his son. She declined. He then obtained power of attorney to pursue the case on behalf of his son.

Until this stage George Young could be seen as a father reasonably concerned, by the standards of the day, by what he regarded as a marriage which might impede his son's career, but his subsequent behaviour reveals some darker aspects of his character. Through a church treasurer he arranged for Margaretha to be examined by a midwife, a ruse to look for signs of other pregnancies which, as she had not seen her husband since 1742, would brand her as an adulteress. No such signs were apparent. He tried to portray her as a woman of easy virtue, a gold digger, even a prostitute who had seduced his son. But the evidence collected in Holland suggested otherwise, that she had been brought up in the 'true reformed Christian tradition' and adhered to that. In one curt, chilling three line letter, which he left unsigned and undated,Young suggests to her that she eats her son. Margaretha won her adherence case, was granted a 'declarator of marriage' gaining maintenance for herself and her son and winning legal costs. ${ }^{30,31}$ Because Margaretha had cohabited with another man in The Hague in 1748, George Young junior was granted a divorce by the Edinburgh Commissary Court in 1750, although Margaretha was again awarded living expenses and costs. ${ }^{31,32}$ Little is known of the fate of her ex-husband, but there is no record of his graduating from the Universities of Leiden or Edinburgh and he does not appear to have embarked on a career in medicine. His brother Thomas, writing his will in 1755, leaves his estate to his father,'failing whom' a list of cousins and uncles, but there is no mention of his brother George. ${ }^{24}$

George Young senior, having refused to reimburse the agents for payments made to his son, lost his case against them at the High Court of Admiralty in London. ${ }^{33}$ Yet he continued to defy this judgement. In 1744 his lawyer Charles Maitland argued '...his son has been engaged in the most idle and extravagant courses....and his father does not feel obliged to reimburse these ruinous advances of money. ${ }^{34}$

We can conclude that George Young senior had ambitions for his son and when these appeared to be threatened he was a determined adversary, who was prepared to be devious, perhaps even ruthless, to achieve his end. The affair had financial repercussions; in April 1746 Young confiscated the labouring cattle and instruments' of the baxter (baker) James Dundas to whom he leased fields and houses at Muirbarns, Kirknewton. He then took 'furniture and household effects' from the houses and refused to pay for house repairs, actions which resulted in further litigation. ${ }^{35}$ 


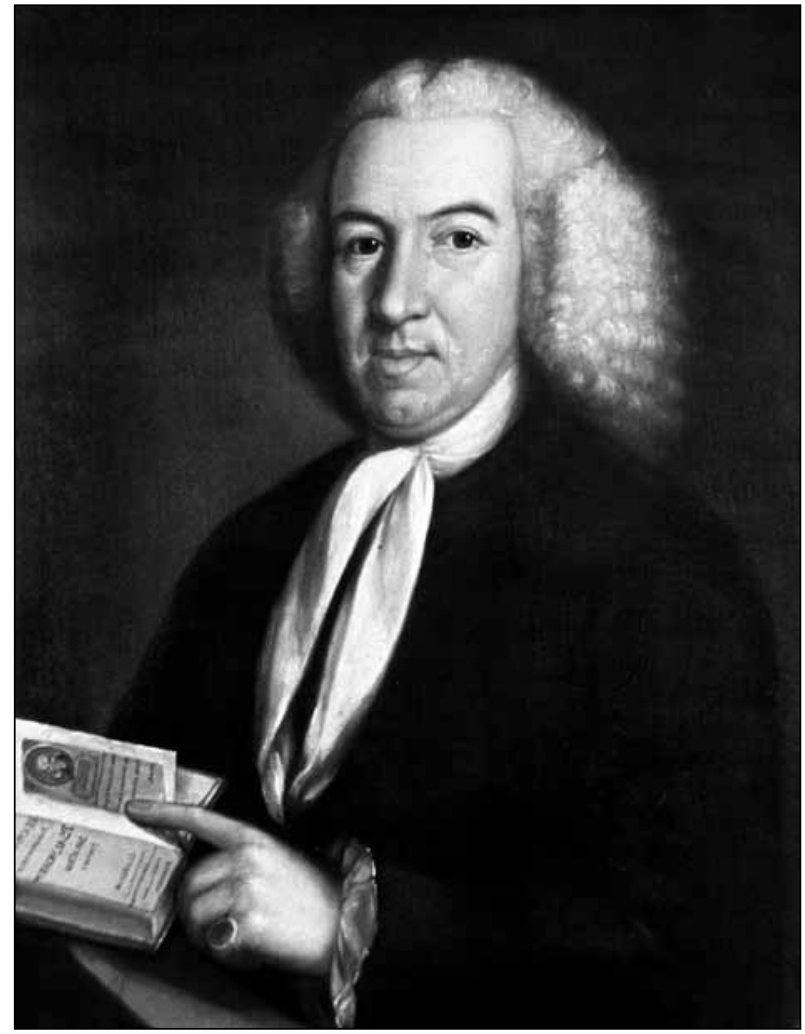

FIGURE 4 John Boswell (1710-1780) the Edinburgh physician who described Young as a 'sceptick and emperick'. By buying the copy of Young's lectures transcribed by Whytt he ensured that Young's writings were available to future generations. Courtesy of RCPE.

\section{YOUNG'S LECTURES}

Young delivered lectures in Edinburgh in I730-I. On the inside cover of the copy of his lectures in the RCPE library, the Edinburgh physician John Boswell (I7I01780) (Figure 4), uncle of the diarist, inscribed:"I bought this book at DrWhytt's sale for it contains a variety of things, amongst others the Dr's [Whytt's] own ms notes when a student of old Dr Young's lectures on his own private practice... Dr Whytt and I were contemporary fellow students of Dr Young's in 1730 31 ... Dr Young was a very sensible, honest, goodnatured man, but a sceptick in medicine (and emperick) as well as in every other thing, confining himself to good, evident common sense. ${ }^{20}$

The references to scepticism, empiricism and evident common sense give an indication of some of the core beliefs which characterised Young's teaching. His surgical background and the influence of his Rankenian friends are apparent throughout his lectures; he repeatedly emphasises the need to rely on observed rather than inferred phenomena before reaching conclusions. His philosophy of medicine based on observation and experience is very much in the tradition of Thomas Sydenham.
The lectures are a comprehensive account of contemporary medical, and some surgical practice. In the style of the day, they include some 20 case reports illustrating common conditions. Lectures are devoted to specific ailments such as smallpox, scurvy, gout, rickets, 'King's evil' and madness. There are accounts of surgical conditions including wounds, ulcers, bladder stone and haemorrhoids and of various treatments, largely based on humoral medicine, including clysters (enemas) and diureticks [sic]. He also discussed chemical (e.g. mercury), herbal and natural remedies such as cooling, cold bathing and 'regimen' (diet and lifestyle).

\section{Nerve function}

It is in the lectures on physiology and on Boerhaave's Institutions that Young's sceptical approach becomes especially apparent. His lecture on nerve and muscle function, recorded by Robert Whytt, challenged conventional theories and here Young contributes to the ongoing quest for an understanding of the relationship between mind and body.

Galenic concepts of a fluid 'animal spirit' flowing down nerves from the brain prevailed until the human anatomical dissections of Vesalius paved the way for alternative explanations. Isaac Newton had suggested that transmission was accomplished by vibration of the 'ether' within the nerves or by pressure. Yet the anatomists had shown that nerves were solid, calling these iatromechanical hypotheses into question.

When Young gave his lectures in $|73|-2$, the theories about nerve function centred around the 'animus', the life force being transmitted along nerves by an as yet unknown mechanism. The experiments that would clarify this were yet to come. What part did Young's lectures play in that clarification? Young considers the various theories that had been postulated. He outlines the views of those who followed the Newtonian iatromechanical theory like James Keill (1673-1719), the Edinburgh physician and anatomist; ${ }^{36}$ Daniel Bernoulli (1700-1782) the Swiss mathematician and physician whose ideas on iatromechanical theory had only recently been published in Hydrodynamica. ${ }^{37}$ Young goes on to discuss the proponents of 'gunpowder theory'. John Mayow (1645-79), the English physician and chemist had developed the gunpowder theory of physiology, believing that nitrous and sulfurous particles in the body were 'engaged in perpetual hostilities with each other'. ${ }^{38}$ Mayow's theory was extended by Thomas Willis (162175) who suggested that blood containing nitrosulphureous particles was pumped into muscles where it met with 'animal spirits' or a nervous fluid, to produce an 'explosion': the particles 'suddenly intumified, as if inkindled and exploded.' The nerve acted as an ignition mechanism, controlled from the brain, producing 'the fiery inkindling or the match... [to] blow up the Muscle'. ${ }^{38}$ 
Yet Willis was clear that nerves were responsible for sensation and muscle movement: 'transmission is performed by the spirits within the nerves... implant[ing] a contracture or elastic force'. Hermann Boerhaave too promoted this hypothesis.

It is clear that Young was well versed in recent and contemporary literature. Having discussed the mechanisms of sensation and of muscular function he concludes that '...the nerves are the instruments of motion some way or another', but, as though unconvinced by these iatrochemical and iatrophysical theories, he goes on to question whether nerve conduction was through liquid or vibration '...or is it by another mechanism?'

It seems certain that these lectures, which he wrote down with such care, inspired Robert Whytt to think further about the topic and influenced his view that an explanation must be based on observation and not by variations on Galenic or Newtonian dogma. Young's rejection of mechanical explanations and his suggestion that laws, other than those of mechanics, applied to bodies, were ideas which Whytt was to take forward. ${ }^{39}$

At much the same time as Young was giving his lectures, the English cleric and physiologist Stephen Hales (1677176I) was making observations based on experiments. $\mathrm{He}$ suggested that 'electrical powers' might be transmitted along nerves. Hales found that a frog continued to jump after it had been decapitated, and that its hind limbs would be withdrawn when a stimulus was applied. These depended on an intact spinal cord. Hales did not publish the experiment but described it in a letter to Robert Whytt, who performed further frog experiments to confirm that reflex activity depended on the segmental integrity of the spinal cord. ${ }^{40} \mathrm{He}$ also described the reflex pupillary response to light and introduced the terminology of stimulus and response. These, including Hales's experiment, were written up by Whytt in a series of publications in $1751 .{ }^{41}$

\section{Muscle function}

Young's interest in the physiology of muscle function clearly continued after the dissertation he gave on the topic in 1719. As before, he begins with a critical analysis of the prevailing theories of muscle function. He rejects these on the grounds that the theories are based on reasoning rather than on observations. 'Keil [sic] never saw the attraction of animal spirits, whoever saw Bernouilli's specula spiritum animalium breaking the Globules of Blood... nobody ever saw the struggling betwixt the acids and alkali's in the blood... nor does Willis pretend to have seen the bloody fray that he supposes in the belly of the muscle in the time of every contraction; The great Boerhaave himself never saw his greater Influx of the animal spirits by which he accounts for muscular motion.'
Indeed Young is scathing about Boerhaave. In a letter to a William Sinclair, a medical student at Leiden, dated 31 May 1737, he expresses a sceptical view of Boerhaave's theories. ${ }^{27}$ 'I have always thought' he writes 'that a man who lays down a settled theory must strain a point to maintain what he has once laid down... Boerhaave makes no more scruple of squeezing facts into a consistency with his theory than a lawyer does of bringing off a [guilty] criminal.... Young considers that it is Boerhaave's eloquence rather than the worth of his hydromechanical theory that has made his reputation, 'As he is a great master of oratory he is thereby capable of doing much good or harm.'

In seeking a valid explanation for muscle function, Young advises his students to start with the observation that the will causes the motion of the muscles. This was mediated, he argues, by 'sensible phenomena', by which he meant phenomena which could be perceived by the senses. In searching for these phenomena Young argues that only those mechanisms which can be detected by the senses should be considered. Do not waste time he urges, in hypothesising by looking for explanations which cannot be seen. Pursuing this course of action might result in 'pursuing invisible mechanisms ad infinitum.' He concluded that 'the will must make use of some instrument to dilate the muscle.'Young's influence on Whytt is seen in the latter's Essay on the Vital and Other Involuntary Motions of Animals published in 1751.40 Here he describes experiments on muscle stimulation, the observed phenomena that Young had promoted. He rejected outright Haller's theory of animal spirits as the mechanism which brought about muscle contraction, arguing that there were no tubules in nerves to allow the flow of such fluid. Although Young is not cited (he had, after all not published on the topic), Whytt's repeated emphasis on observation as the basis for hypothesis echoes the doctrine of his former teacher.

Whytt of course had other influences including Willis, Boerhaave, Stahl and Alexander Stuart. Could his thinking on the topic have been influenced by his other great Edinburgh teacher Alexander Monro primus? In his extensive lecture series Monro devoted little time to the subject of nerve and muscle function. ${ }^{42}$ In marked contrast to the scepticism of Young, Monro presented the traditional Galenic view of 'fluid' in nerves and his passing reference to the views of Keill and Bernouilli, takes an uncritical view of hydromechanical theory.

Young's philosophy was rooted in his training as a surgeon. Stott concluded that 'in Young's lectures we see the continuing tradition of surgeon-apothecaries critical of medical knowledge obtained other than through the evidence of external sensory perception. ${ }^{43}$ 


\section{TREATISE ON OPIUM (I753)}

Opium was widely prescribed by doctors but there were very few treatises on the topic to guide its use. Young's contemporary Charles Alston, professor of botany and materia medica at Edinburgh University had published a seminal paper in 1742 in which he described opium's history and its preparation from poppies he had grown, the first person in Britain to have done so. ${ }^{44} \mathrm{He}$ described detailed chemical experiments and experiments assessing its properties using frogs and dogs. Although his was the most objective, rational and scientific account to date, Alston wrote curiously little about the side-effects and nothing about addiction, previously well described. 'Opium' he concluded 'does more honour to medicine than any other remedy whatever'. Young's treatise seems to have been stimulated as a response to this, since, at the outset he emphasises the risks '...that I may prevent such mischief as I can, I here give it as my sincere opinion... that opium is a poison by which great numbers are daily destroyed. ${ }^{45}$

In a thinly veiled reference to Alston, and true to his reputation as a sceptic, Young is fiercely critical about writers who have described chemical or animal experiments: '...but how little satisfaction do we find in reading their accounts! How much are we disappointed when we come to compare these observations with our own experience!' Thereafter he describes his considerable experience with the drug and makes little reference to the experience of others.

In 41 chapters over 182 pages the treatise sets out the effects of the drug and its uses in a variety of conditions, including his use of the drug for his own chronic cough and diarrhoea. Thus he advocates its use in small doses (20 rather than 30 drops) as a cough suppressant. He describes its use in treating diarrhoea, urging caution as in higher doses it is more likely to produce nausea and vomiting in those with diarrhoeal illnesses. Other painful conditions in which he finds it effective include toothache, tenesmus, prolapsed haemorrhoids, and labour pains. Yet he advised against its use for 'a small stone in the kidney or ureters because opium will hinder nature from exerting itself in expelling it.' This view became widely accepted into medical practice for more than two centuries. For decades pethidine was regarded as the least likely to produce this effect, until opiates were superseded by non-steroidal anti-inflammatories as drugs of first choice in this situation. ${ }^{48}$

Young described the use of opium for 'lowness of the Spirits' and melancholia. He advocated its use in surgery as premedication: 'Opium taken 2 or 3 hours before the operation gives courage and steadiness, both of body and mind.' Yet, unlike some of his contemporaries he did not prescribe it routinely during operations, concerned that it made the patients sleepy.
The treatise represents a valuable guide to prevailing knowledge and practice from an experienced practitioner, with a clear warning about the risks of opium. It was the largest, clearest, most balanced and most comprehensive account to that time in English.

The work of Young and of Alston on opium had a major influence on Whytt, whose later experiments concluded that opium acted on the nerve endings and the medulla, a view which took him into conflict with Monro secundus and Haller. ${ }^{47}$

\section{YOUNG'S APPRENTICE JAMES HILL}

Young's legacy is also apparent in the thinking of one of the surgeons whom he trained. Of Young's 12 known apprentices one, James Hill (I703-I776), was to make important contributions to the understanding and management of head injury. Hill was apprenticed to James Young in 1723 and returned to his native Dumfries where he set up in practice as a surgeon in 1732. ${ }^{3}$ Some 40 years later he published Cases in Surgery which was in effect an account of the cases that he had treated over a working lifetime in surgery, considered under three headings, head injury, cancers and sibbens. ${ }^{48}$

Cases is set out in considerable detail and with great clarity. In his series of 18 cases of cranial trauma Hill's mortality rate was only $16 \%$, much lower than other contemporary published series, such as those of Le Dran (57\%) and Potts (5l\%), although both were similar to Hill's in terms of severity of trauma. ${ }^{49}$ This is partly explained by a much lower infection rate. Yet it is clear that Hill understood concepts based on observation, a discipline which must have been instilled into him by Young. Thus he appreciated the importance in skull fracture of brain pulsation, of when and where to trepan to relieve brain compression. A detailed account and analysis of Hill's series is given elsewhere. ${ }^{49}$

Hill's influence continued to be felt long after his death. His work was cited by later authorities such as John Bell, $^{50}$ John Abernethy ${ }^{51}$ and WHA Jacobson, ${ }^{52}$ the last writing over 150 years after Hill's death. This reputation was related to his management of head injuries which showed a willingness to be guided by his own observation and experience rather than the writing of others. Like Young he was a sceptic, ready to criticise authorities when their views did not match his observations.

\section{YOUNG'S INFLUENCE AND LEGACY}

As a Rankenian, Young would have spent formative years with some of the most influential thinkers of his generation. David Hume is known to have met Rankenians, but we can only speculate about their 
influence during his years at Edinburgh University from I72I to 1725, years when Young was a club member. Hume's Treatise of Human Nature was planned before he was 21 years old and composed before he was $25 .^{53} \mathrm{At}$ the heart of Hume's philosophy was the emphasis on observation and experience, a recurring theme in Young's teaching. Hume was to write 'as the science of man is the only solid foundation for the other sciences, so the only solid foundation we can give to this science itself must be laid on experience and observation'.54 Young, recognised by Whytt (and presumably by other contemporaries) as a sceptic and empiric, may well have influenced the early thoughts on the doctrine of empiricism developed by Hume and that of scepticism with which he is associated.As Fosl has pointed out, the similarities between Young's lectures and what became Hume's analysis of causation, probability, and practice are striking. ${ }^{55}$ The Rankenians discussed ideas later elaborated by Hume, and Davie considered that they were one of the determining influences in his ideas. ${ }^{10}$

Young's emphasis on observation and scepticism and his critical and questioning analysis of nerve and muscle function would surely have inspired his pupil Robert Whytt in his development of the sentient principle, that force which conveyed sensation along the sensory nerves and initiated motion in muscles. That emphasis on refusal to accept established wisdom unless supported by experience and observation is evident in the writings and the results of James Hill, trained in the Young tradition.

\section{CONCLUSION}

Why did such an important figure not merit a biography or tributes from contemporaries or pupils? It is possible that because of the scandal resulting from events around his son's divorce and his legal battles with James Dundas, he had lost friends, respect and influence. Yet despite that, George Young emerges as an important figure in Edinburgh medical teaching. The central tenet of his medical philosophy was that the only valuable knowledge was that derived from experience i.e. provided by the senses and this was, in later years, to become a core belief of the Enlightenment.Young's entry in the Dictionary of Eighteenth Century British Philosophers ${ }^{17}$ and in the British philosophers section of the Dictionary of Literary Biography ${ }^{55}$ attests to his status as a philosopher but his influence deserves greater recognition and appreciation.

\section{Acknowledgements}

I am grateful to Jeremy Ganz for suggesting the article and reading the manuscript and to Helen Dingwall for many helpful suggestions. My thanks to lain Milne and Estela Dukan at the RCPE Library and Marianne Smith and Steve Kerr at the RCSEd Library for invaluable help.

\section{REFERENCES}

I Disposition by Mr Thomas Young to Dr George Young and others. Edinburgh: National Archives of Scotland, GD/98/27/I I; 1755.

2 Grant FJ,Watson CBB,Wood M. The register of apprentices of the City of Edinburgh, 1583-1666. Edinburgh: Scottish Record Society; 1906.

3 Wallis PJ,Wallis R,Whittet T. Eighteenth century medics: subscriptions, licenses, apprenticeships. Newcastle: University of Newcastle; 1985.

4 Dingwall HM. Physicians, surgeons and apothecaries: medicine in seventeenth-century Edinburgh. East Linton:Tuckwell Press; 1995

5 Minutes 20 May; 14 July; 21 July; 27 August I7/9. Edinburgh: Royal College of Surgeons of Edinburgh.

6 Broadie A. The Scottish Enlightenment: the historical age of the historical nation. Edinburgh: Birlinn; 200I.

7 McElroy DD. Scotland's age of improvement: a survey of eighteenthcentury literary clubs and societies. Pullman: Washington State University Press; 1969.

8 Stewart D. Account of the life and writings of William Robertson, DD, FRSE. London: Cadell \& Davies; I80I.

9 Graham R. The great infidel: a life of David Hume. Edinburgh: Birlinn; 2004.

10 Davie GE. The Scotch metaphysics: a century of Enlightenment in Scotland. London: Routledge; 200 I. http://dx.doi.org/I0.4324/978020347I I59

II Stewart MA. Berkeley and the Rankenian Club. Hermathena: A Trinity College Dublin Review 1985; 139:24-45.

12 Broadie A. The Scottish Enlightenment: an anthology. Edinburgh: Canongate; 1997.

13 Woodhouselee AFT. Memoirs of the life and writings of the Honourable Henry Home of Kames. Edinburgh: printed for William Creech and T. Cadell and W. Davies; 1807.

14 Mossner EC. The life of David Hume. 2nd ed. Oxford: Clarendon Press; 1980.

I5 Emerson RL. Essays on David Hume, medical men and the Scottish Enlightenment: industry, knowledge and humanity. Farnham: Ashgate; 2009

I6 Macintyre IMC, MacLaren I. Surgeons' lives: Royal College of Surgeons of Edinburgh: an anthology of college fellows over 500 years. Edinburgh: Royal College of Surgeons of Edinburgh; 2005.

17 Yolton JW, Price JV, Stephens JN. The dictionary of eighteenth-century British philosophers. Bristol:Thoemmes; 1999.

18 Emerson RL. The founding of the Edinburgh medical school.J Hist Med Allied Sci 2004; 59:I83-2/8. http://dx.doi.org/I0.1093/jhmas/ jrh066

19 Dalzel A, Innes C. History of the University of Edinburgh from its foundation. Edinburgh; Edmonston \& Douglas; 1862.

20 Young G. Lectures on medicine. Edinburgh: Royal College of Physicians of Edinburgh; I730-I.

21 University of St Andrews. Muniments. University of St Andrews; UV452/4/2II.

22 Annuity Tax. Edinburgh City Archives; I75I.

23 Houston R, van der Heijden M. Hands across the water: the making and breaking of marriage between Dutch and Scots in the mid-eighteenth century. Law and History Review 1997; I5:2I5-42. http://dx.doi.org/ I0.2307/82765 I

24 Disposition of Mr Thomas Young to Dr George Young and others. 8 October 1755. Edinburgh: National Archives of Scotland, GD98/27/II; 1755.

25 Hoolihan C. Thomas Young, M.D. (I726?-I783) and obstetrical education at Edinburgh. J Hist Med Allied Sci 1985; 40:327-45. http://dx.doi.org/I0.1093/jhmas/40.3.327

26 Aeneas Macdonald factor at Paris and Messers Grant and Crawford factors at Rotterdam v Mr George Young in Edinburgh and George Young his son. Expenses of education in surgery abroad. 28 July 1742. Edinburgh: National Archives of Scotland, GD/50/216/45; 1742.

27 Young G. Letter to William Sinclair, student of medicine Leiden concerning his studies. Edinburgh, National Archives of Scotland, GD |36/376; I 737.

28 National archives currency converter [Internet].[cited 2012 Oct 3I]. Available from: http://www.nationalarchives.gov.uk/currency/ 
29 Smith RWI. English-speaking students of medicine at the University of Leyden. Edinburgh: Oliver and Boyd; 1932.

30 Declarator of marriage: Margaret Cassa v George Young. Edinburgh: National Archive of Scotland, CC/8/6/330; 1749.

31 Grant FJ, ed. The Commissariot of Edinburgh. Consistorial processes and decreets 1658-1800. Edinburgh: Scottish Record Society; 1909.

32 Process of divorce: George Young $v$ Margaret Cassa. Edinburgh: National Archives of Scotland, CC/8/6/333; 1750.

33 Information for Aeneas Macdonald, factor at Paris and Messers Grant and Crawford, factors at Rotterdam v Dr George Young physician and his son George Young 20 Dec 1743. Edinburgh: National Archives of Scotland, GD 50/216/45; 1743.

34 Information for George Young Physician at Edinburgh against Aeneas Macdonald, Factor at Paris. Edinburgh: National Archives of Scotland GD 50/216/45; 1744.

35 James Dundas baxter, burgher, Edinburgh vs George Young, physician Edinburgh. Edinburgh: National Archives of Scotland, CSI8I/7484; 1746.

36 Keill J. An Account of animal secretion, the quantity of blood in the humane body, and muscular motion. London: George Strahan; 1708.

37 Bernoulli D. Hydrodynamica, sive de viribus et motibus fluidorum commentarii, etc. Argentorati: sumptibus Johannis Reinhold Dulseckeri; 1738.

38 Mayow J. Medico-physical works; being a translation of Tractatus quinque medico-physici (1674). Edinburgh: Albemic Club; 1907. http://dx.doi.org// 0.5962/bhl.title.28895

39 Wright JP. Metaphysics and physiology. In: Stewart MA, ed. Studies in the philosophy of the Scottish Enlightenment. Oxford: Clarendon; 1990.

40 Whytt R. An essay on the vital and other involuntary motions of animals. Edinburgh: Hamilton, Balfour and Neill; I75I. http://dx.doi. org/10.1037/II796-000

4I French RK. Robert Whytt, the soul, and medicine. London:Wellcome Institute of the History of Medicine; 1969.

42 Monro A. Lectures. Edinburgh: Royal College of Surgeons of Edinburgh; |73I.
43 Stott R. The Incorporation of surgeons and medical education and practice in Edinburgh 1696- 1755 [PhD thesis]. Edinburgh:University of Edinburgh; 1984.

44 Alston C. A dissertation on opium. Medical Essays and Observations 1742; 5:110-77.

45 Young G. A treatise on opium, founded upon practical observations. London: printed for A Millar; 1753.

46 O'Connor A, Schug SA, Cardwell H. A comparison of the efficacy and safety of morphine and pethidine as analgesia for suspected renal colic in the emergency setting. J Accid Emerg Med 2000; I7:26 I-4. http://dx.doi.org/I0.II36/emj.I7.4.26I

47 Whytt R, Whyte-Melville J. The works of Robert Whytt. Edinburgh: Balfour, Auld, and Smellie; 1768.

48 Hill J. Cases in surgery, particularly of cancers, and disorders of the head from external violence. With observations. To which is added an account of the sibbens. Edinburgh: John Balfour; 1772.

49 Granz J, Macintyre IMC. Traumatic brain injury in the I8th century; a journey towards clarity. Forthcoming 2013.

50 Bell J. The principles of surgery, in two volumes. Edinburgh, London: Printed for T. Cadell, jun. \& W. Davies, in the Strand, T.N. Longman \& O. Rees, Paternoster-Row and W. Creech, P. Hill, and Manners and Miller; 180I.

5I Abernethy J. Surgical observations on injuries of the head; and on miscellaneous subjects. London; Longman: Hurst, Rees, Orme and Brown; 1810.

52 Jacobson WHA. The operations of surgery. 5th ed. London; J \& A Churchill; 1907.

53 Hume D. Essays, moral, political, and literary. Edinburgh; 174I.

54 Hume D. A treatise of human nature: being an attempt to introduce the experimental method of reasoning into moral subjects. London: Printed for John Noon, at the White-Hart, near Mercer's-Chapel, in Cheapside; 1739.

55 Fosl PS. British philosophers, I 500-1799. In: Dematteis PB, FosI PS, eds. Dictionary of literary biography. Detroit: Gale Group; 2002. pp. 195-223. 